\title{
ANALISIS LARANGAN AKTIVITI \\ KEAGAMAAN DI MASJID DALAM \\ PERUNTUKAN PERINTAH KAWALAN \\ PERGERAKAN (PKP) BERDASARKAN \\ PARAMETER MAQT̄STID AL-SHARI'AH
}

\section{Analysis of Religious Activities' Prohibition in Mosques in the Movement Control Order (MCO) Based on the Maqūșid al-Sharī'ah Parameters}

\author{
Muhammad Safwan Harun* \\ Luqman Haji Abdullah** \\ Syed Mohd Jefferi Syed Jaafar ${ }^{* * *}$ \\ Mohd Farhan Md Ariffin ${ }^{* * * *}$
}

\begin{abstract}
This article discusses the position of religious activities in the mosque during the outbreak of
\end{abstract}

* Senior Lecturer, Department of Fiqh and Usul, Academy of Islamic Studies, University of Malaya, 50603 Kuala Lumpur. safone_15@ um.edu.my

** Corresponding author, Senior Lecturer, Department of Fiqh and Usul, Academy of Islamic Studies, University of Malaya, 50603 Kuala Lumpur. luqmanabdullah@um.edu.my

*** Senior Lecturer, Department of Fiqh and Usul, Academy of Islamic Studies, University of Malaya, 50603 Kuala Lumpur. syedjeffri89@um.edu.my

**** Senior Lecturer, Academy of Islamic Civilization Faculty of Social Science and Humanities Technology University of Malaysia Skudai, 81300 Johor Bahru, Johor. mohdfarhan.ma@utm.my 
the COVID-19 pandemic from the perspective of the maqāsid al-sharī'ah (the higher objectives of Sharia). The Government of Malaysia gazetted a suspension of all religious activities at the mosque through the issuance of Movement Control Order (MCO) which has led to juristical debate as to what extent it can be imposed on the Muslim community in Malaysia. This issue needs to be clarified in order to evaluate the implementation of the MCO and its justification for prohibiting religious activities in accordance with the Islamic law and the principle of maquassid al-shari' 'ah. This study concludes that the prohibition of religious activities is in line with the parameters of the maqāsid al-shari'ah, which precedes the mașlahah of life (darürī) rather than the mașlahah of religion (al-häjiyyāt). In fact, this provision also follows the method of درء المفاسد اولى من جلب المصأ (prioritizing repelling the harms over securing the benefits) to prevent the spread of COVID-19. However, there are some technical details that should be observed and might be proposed for the betterment of the MCO gazette in relation to the religious activities in the mosque.

Keywords: maqāṣid al-sharī'ah, worship, Movement Control Order, mașlahah, COVID-19

\section{PENDAHULUAN}

Umum mengetahui tentang wabak Corona Virus Disease 2019 (COVID-19) pertama kali telah ditemui di Wuhan, China pada 31 Disember 2019'. Sungguhpun kes pertama COVID-19 berlaku di China, namun sehingga ke hari ini ia telah mencatatkan 337553 kes di 192 negara di mana antara yang turut terkesan ialah Malaysia

Matt Reynolds, "What is coronavirus and what happens now it is a pandemic?," laman sesawang Wired, dicapai pada 25 Mac 2020, https://www.wired.co.uk/article/china-coronavirus. 
dengan jumlah kes sebanyak 1,306 setakat 22 Mac 2020. ${ }^{2}$ Kes-kes yang dicatatkan ini, menunjukkan bahawa COVID-19 merupakan satu virus baru yang mudah tersebar dalam kalangan masyarakat dunia. Lantaran itu, pada 18 Mac 2020 World Health Organisation (WHO) telah mengistiharkan COVID-19 sebagai penyakit pandemic ${ }^{3}$ untuk memberi amaran kepada dunia tentang ancaman virus ini. ${ }^{4}$ Keadaan ini sekali gus menimbulkan kegusaran dalam kalangan masyarakat dunia.

Keadaan lebih sukar kerana sehingga kini COVID-19 tidak mempunyai kaedah rawatan yang khusus. Apatah lagi, sebarang vaksin bagi tujuan pencegahannya masih tidak ditemui. Sekalipun terdapat inovasi satu vaksin baru yang dikatakan boleh merawat COVID-19, namun ianya masih di peringkat kajian. ${ }^{5}$ Lantaran itu, virus ini terus tersebar dengan kadar jangkitan yang tinggi daripada seorang individu kepada individu yang lain melalui sentuhan langsung, udara dan percikan air liur melalui batuk dan bersin. Ini ditegaskan oleh Dr. Maria Van Kerkhove yang merupakan ketua Unit Penyakit Baru dan Zoonosis:

"It's very important that health-care workers take additional precautions when they're working on patients and doing those procedures." World health officials say the respiratory disease spreads through human-to-human contact, droplets carried through sneezing and coughing as well as germs left on in-

2 Report coronavirus cases, "Confirmed Cases and Deaths by Country, Territory, or Conveyance," laman sesawang Worldometer, dicapai pada 25 Mac 2020, https://www.worldometers.info/ coronavirus/\#countries.

3 World Health Organization, "Rolling updates on coronavirus disease (COVID-19)," laman sesawang World Health Organization, dicapai pada 27 Mac 2020, https://www.who.int/emergencies/diseases/ novel-coronavirus-2019/events-as-they-happen.

4 Kimberly Hickok, "What is a pandemic?", laman sesawang LiveScience, dicapai pada 26 Mac 2020, https://www.livescience. com/pandemic.html.

5 Anthony Fauci, "COVID-19: Ujian Pertama Vaksin Ke Atas Manusia Bermula Di AS," laman sesawang BHOnline, dicapai pada 24 April 2020, https://www.bharian.com.my/dunia/amerika/2020/03/666859/ covid-19-ujian-pertama-vaksin-ke-atas-manusia-bermula-di. 
animate objects. The coronavirus can go airborne, staying suspended in the air depending on factors such as heat and humidity, they said. ${ }^{6}$

Memandangkan tiada rawatan khusus dalam kaedah rawatan moden, maka langkah yang hanya boleh diambil oleh kerajaan bagi menangani penularan wabak COVID-19 hanyalah melalui kaedah kuarantin kepada seluruh rakyat sesebuah negara. Hal ini bagi mengurangkan contact rate antara individu yang sakit dan sihat. Langkah ini bukan sahaja diambil oleh Malaysia melalui Akta Pencegahan dan Pengawalan Penyakit Berjangkit 1988 dan Akta Polis 1967 untuk melaksanakan Perintah Kawalan Pergerakan (PKP), ${ }^{7}$ malah lebih awal dilakukan oleh beberapa negara lain seperti China, Denmark, El Salvador, France, Ireland, Itali, New Zealand, Poland, and Sepanyol. ${ }^{8}$ Sekalipun langkah ini mempunyai tujuan yang jelas iaitu mencegah penularan penyakit berjangkit COVID-19, namun terdapat kesan sampingan yang tidak sihat terhadap aktiviti masyarakat.

Seperti yang dijelaskan, Malaysia turut terlibat dengan pencegahan penularan virus COVID-19 melalui kaedah lockdown atau lebih tepat kuarantin. Tindakan ini bermula pada 18 Mac 2020 dan dijangka berakhir pada 12 Mei 2020 setelah berlaku kenaikan mendadak kes jangkitan akibat perhimpunan tabligh di Masjid Jamek Seri Petaling yang boleh disifatkan sebagai

6 Berkeley Lovelace Jr., Noah Higgins-Dunn dan William Feuer, "WHO considers 'airborne precautions' for medical staff after study shows coronavirus can survive in air," laman sesawang $C N B C$, dicapai pada 27 Mac 2020, https://www.cnbc.com/2020/03/16/whoconsiders-airborne-precautions-for-medical-staff-after-study-showscoronavirus-can-survive-in-air.html.

7 Muhyiddin Haji Muhammad Yassin, "Perutusan Khas YAB Perdana Menteri Mengenai COVID-19 - 16 Mac 2020," laman sesawang Pejabat Perdana Menteri Malaysia, dicapai pada 27 Mac 2020, https://www.pmo.gov.my/ms/2020/03/perutusan-khas-yab-perdanamenteri-mengenai-covid-19-16-mac-2020-2/.

8 Holly Secon, Lauren Frias dan Morgan McFall-Johnsen, “A running list of countries that are on lockdown because of the coronavirus pandemic," laman sesawang Business Insider Malaysia, dicapai pada 24 Mac 2020, https://www.businessinsider.my/countries-onlockdown-coronavirus-italy-2020-3?r=US\&IR $=\mathrm{T}$,. 
kes kluster. ${ }^{9}$ Kesan daripada kes kluster tersebut, Malaysia terus mencatatkan pertambahan kes-kes COVID-19 baru dari hari ke hari. Lantaran itu, kerajaan Malaysia mengambil langkah segera dengan mengeluarkan Perintah Kawalan Pergerakan.

Ringkasnya, PKP merupakan satu perintah bagi mengurangkan pergerakan masyarakat di Malaysia bagi mengekang contact rapat antara individu pembawa COVID-19 dengan individu yang sihat. Sungguhpun, objektif PKP adalah releven dengan suasana kritikal yang dihadapi masyarakat, namun ia turut memperuntukkan supaya segala aktiviti yang menjurus kepada perkumpulan dihentikan. Hal ini termasuklah aktiviti keagamaan di masjid dan surau yang menyebabkan terhentinya solat jemaah dan solat Jumaat. Perkara ini jelas termaktub dalam pengumuman oleh Perdana Menteri Malaysia:

Pertama, larangan menyeluruh pergerakan dan perhimpunan ramai di seluruh negara termasuk aktiviti keagamaan, sukan, sosial dan budaya. Untuk menguatkuasakan larangan ini, semua rumah ibadat dan premis perniagaan 2 hendaklah ditutup, kecuali pasaraya, pasar awam, kedai runcit dan kedai serbaneka yang menjual barangan keperluan harian. Khusus untuk umat Islam, penangguhan semua aktiviti keagamaan di masjid dan surau termasuk Solat Jumaat adalah selaras dengan keputusan Mesyuarat Jawatankuasa Muzakarah Khas yang telah bersidang pada 15 Mac 2020. ${ }^{10}$

9 Noor Hisham Abdullah, "Kenyataan Akhbar KPK 20 Mac 2020 -Situasi Semasa Jangkitan Penyakit Coronavirus 2019 (COVID-19) di Malaysia," laman sesawang Director-General of Health Malaysia, dicapai pada 27 Mac 2020, https://kpkesihatan.com/2020/03/20/ kenyataan-akhbar-kpk-20-mac-2020-situasi-semasa-jangkitanpenyakit-coronavirus-2019-covid-19-di-malaysia/.

10 Muhyiddin Haji Muhammad Yassin, "Perutusan Khas YAB Perdana Menteri Mengenai COVID-19 - 16 Mac 2020," laman sesawang Pejabat Perdana Menteri Malaysia, dicapai pada 27 Mac 2020, https://www.pmo.gov.my/ms/2020/03/perutusan-khas-yab-perdanamenteri-mengenai-covid-19-16-mac-2020-2/. 
Umumnya, PKP memperincikan larangan perhimpunan di masjid dan surau memandangkan majoriti masyarakat Malaysia adalah muslim yang akan berhimpun pada setiap waktu solat fardhu dan solat Jumaat. Namun begitu, terdapat segelintir pihak yang merespon sebaliknya dengan mempersoalkan kewajaran aktiviti seperti solat jemaah dan solat Jumaat dihentikan. Hal ini dapat dilihat dengan kenyataan seperti "kami lebih takutkan Allah $S W T$ "11 serta tindakan sebahagian umat Islam yang terus melanggar perintah tersebut dengan menunaikan solat jemaah secara senyap. Malah, jika diperhatikan secara global terdapat juga negara seperti Pakistan yang masih tidak menghentikan aktiviti masjid $^{12}$ walaupun corak fatwa-fatwa dunia Islam dalam isu ini menjurus kepada larangan meneruskan ibadah di masjid.

Sekalipun PKP mempunyai asas yang jelas dalam syariat untuk menghalang aktiviti ibadat di waktu wabak, namun satu aspek yang perlu dijelaskan lagi adalah sudut objektif syarak terhadap larangan ini. Bermakna, sungguhpun asas larangan menepati syariat Islam bersandarkan hadis yang akan dibahaskan, namun perintah ini tidak dapat difahami dengan baik melainkan aspek maqūṣid al-sharī'ah dibahaskan secara tuntas dalam kajian ini. Ini kerana, maqāssid al-sharī'ah berperanan penting dalam menonjolkan relevansi pensyariatan, fatwa dan hukum sehingga dapat diterima dengan baik oleh akal yang sejahtera. Oleh kerana itu, kajian ini dibangunkan untuk menjelaskan pensyariatan ibadat seperti solat jemaah dan Jumaat, perintah larangan solat jemaah dan solat Jumaat menurut hukum Islam serta menilai perintah tersebut berdasarkan parameter maqāssid al-sharī'ah.

11 Sinar Harian, "Ribuan tabligh dari seluruh Asia berhimpun di Indonesia," laman sesawang Sinar Harian, dicapai pada 28 Mac 2020, https://www.sinarharian.com.my/article/74411/KHAS/ Koronavirus/Ribuan-tabligh-dari-seluruh-Asia-berhimpun-diIndonesia.

12 Arsalan Khan, "Why Pakistan isn't closing mosques despite the coronavirus threat," laman sesawang TRTWorld, dicapai pada 29 Mac 2020, https://www.trtworld.com/opinion/why-pakistan-isn-tclosing-mosques-despite-the-coronavirus-threat-34913. 
Analisis Larangan Aktiviti Keagamaan di Masjid dalam Peruntukan

Perintah Kawalan Pergerakan (PKP) Berdasarkan Parameter Maqāṣid al-Sharī'ah

\section{PENSYARIATAN SOLAT BERJEMAAH DI MASJID DAN SURAU}

Solat berjemaah secara amnya membawa maksud solat yang dilakukan lebih daripada seorang atau dilaksanakan secara beramai-ramai. Menurut al-Zuhaylī, solat berjemaah merupakan solat yang terhasil di antara pertalian imam dan makmum. ${ }^{13}$ Berhubung hukum solat jemaah, umumnya para ulama bersepakat mengenai pensyariatannya berdasarkan dalil yang thābit dari alQuran, al-Sunnah dan al-Ijmā'. Sungguhpun terdapat sandaran yang jelas, namun demikian para ulama tidak sepakat tentang hukum solat jemaah kerana terdapat aliran yang mewajibkan dan sebahagian aliran yang mensunatkannya.

Hal ini dapat diperhatikan misalnya aliran al-Hanafiyyah dan al-Malikiyyah yang berpandangan solat berjemaah selain daripada solat Jumaat adalah sunat muakkad. Menurut fuqaha Syafi'iyyah dalam pandangan yang asah, hukum menunaikan solat fardu secara berjemaah adalah fardu kifayah. Pandangan ketiga, menurut fuqaha Hanabilah, hukum solat fardu secara berjamaah adalah fardu ain. ${ }^{14}$ Daripada perbincangan di atas dapat dilihat bagaimana terdapat perselisihan dalam kalangan fuqaha mengenai hukum mengerjakan solat fardu secara berjamaah. Setiap pandangan yang dinyatakan masing-masing mempunyai asas yang kukuh berdasarkan kekuatan dan konteks tersendiri. Namun mereka sepakat menyatakan bahawa berjemaah merupakan syarat sah bagi solat Jumaat.

Sebagaimana terdapat perbezaan dalam kalangan fuqaha berhubung hukum mendirikan solat secara berjemaah, begitu juga terdapat perbezaan fuqaha berhubung mendirikan solat berjamaah di masjid. Misalnya, fuqaha Hanafiyyah dan Malikiah ${ }^{15}$ berpandangan mendirikan solat berjamaah di masjid adalah sunat muakkadah. Manakala fuqaha Syafi'iyyah, berpandangan hukum mendirikan solat berjemaah di masjid adalah fardu kifayah kerana

13 Wahbah al-Zuhaylī, Fiqh Islāmī wa Adillatuh (Damsyik: Dār al-Fikr, 1985) 2:146.

14 Al-Zuhaylī, Fiqh Islāmī, 2:146.

15 Ibn 'Abd al-Bārr, al-Istidhkār (Bayrūt: Dār Kutub 'Ilmiyyah, 2000) 2: 133,137 . 
ia merupakan sebahagian daripada syiar agama. ${ }^{16}$ Sementara menurut mazhab Hanbali, mereka merumuskan hukum solat jemaah di masjid sebagai fardu ain yang dituntut kepada lelaki yang cukup syarat dan mendengar seruan azan dikumandangkan. ${ }^{17}$ Walau bagaimanapun, berjemaah bukanlah sebahagian daripada syarat sah solat sebagaimana yang dinyatakan oleh golongan Zahiriyyah. ${ }^{18}$ Dalam isu ini, Wahbah al-Zuhaylī merumuskan mendirikan solat berjamaah di masjid adalah lebih afdal dikerjakan berbanding jemaah di rumah berdasarkan hadis Rasulullah SAW: ${ }^{19}$

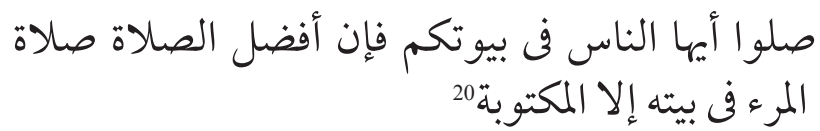

Maksudnya: "Solatlah kamu semua wahai manusia di rumah-rumah kamu, kerana sesungguhnya sebaik-baik solat seseorang di rumahnya melainkan solat fardu."

Ini kerana, masjid mempunyai kelebihan dari sudut kemuliaan, kebersihan, menzahirkan syiar Islam dan ramai jamaah. Hadith ini menunjukkan bahawa solat berjemaah di masjid lebih utama dikerjakan tanpa menafikan kesahihan solat jemaah di rumah. Menariknya, rumusan al-Zuhaylī dalam isu ini adalah selari dengan apa yang telah ditegaskan Imam al-Shāfi'̄i:

"Setiap jamaah lelaki yang solat sama ada di rumah atau di masjid kecil atau besar, jamaah yang sedikit atau banyak ianya tetap dikira, namun kelebihan masjid yang besar dan ramai jamaah lebih dicintai

16 Muḥammad al-Zuhaylī, al-Mu'tamad fì al-Fiqh al-Shāfi'ì, (Damsyik: Dār al-Qalam, 2011) 406.

17 Șāliḥ Ibn Ghanim al-Sadlan, Ṣolāt al-Jamā'ah, (Riyāḍ: Dār Balansiah, 1416h) 57, 58 .

18 Ibid, 59.

19 Al-Zuhaylī, Fiqh Islāmī, 2: 152.

20 Abū Bakr al-Bayhaqī, Ma rifah al-Sunan wa al-Āthār, ditahqiqkan oleh 'Abd al-Muț'ī Amīn Qal'ajīi, Bāb Qiyām Ramaḍān, no. Hadith 5394, (al-Qāhirah: Dār al-Wafā', 1991), 4: 36. 


$$
\text { di sisi saya", }{ }^{21}
$$

Jika diteliti sirah baginda Rasulullah SAW, baginda SAW tidak mendirikan solat berjemaah di masjid ketika mana baginda dan para sahabat berada di Makkah selama 13 tahun, ${ }^{22}$ berikutan ancaman dari kaum kafir Quraysh. Namun setelah tiba di Madinah, perkara pertama yang dilakukan oleh baginda Rasulullah SAW adalah mendirikan masjid di Quba. Hal ini menunjukkan bertapa penting peranan masjid bagi umat Islam. Demikian juga solat Jumaat pertama didirikan dalam Islam adalah di Madinah.

Justeru itu, dapat dirumuskan bahawa persoalan tentang solat jemaah mahupun melaksanakan ibadah ini di masjid ditangani dengan pandangan yang pelbagai oleh para fuqaha. Sungguhpun begitu, perlu ditegaskan bahawa solat berjemaah di masjid memiliki objektif keagamaan yang agung iaitu menghidupkan syiar Islam di atas muka Allah SWT.

\section{LARANGAN SOLAT JEMAAH DI MASJID DAN SURAU DI BAWAH PERINTAH KAWALAN PERGERAKAN MENURUT HUKUM ISLAM}

Dunia menyaksikan bahawa seluruh negara-negara Islam yang terjejas akibat wabakCOVID-19 khususnya Malaysia berada dalam dilema antara melaksanakan tuntutan agama iaitu mengerjakan ibadah jama'i di masjid ataupun menjaga kepentingan nyawa. Di Malaysia, larangan mengerjakan sebarang aktiviti keagamaan adalah jelas ditegaskan dalam PKP. Namun begitu, apakah asas PKP terhadap larangan aktiviti ibadat dalam kalangan umat Islam di Malaysia? Ini kerana, satu kaedah mazhab Maliki menyebutkan al-imām lā madkhal lahu fì al-ibādat (pemimpin tidak mempunyai ruang untuk mentabdir bidang ibadah). Lantaran itu, benarkah PKP selari dengan syariat serta wajib diikuti oleh seluruh

21 Muhammad Ibn Idrīs al-Shaāfi'̄̄, al-Umm (t:t.: Dār al-Ma'rifah, 1393) 1: 154.

22 Pensyariatan solat lima waktu bermula selepas peritstiwa israk dan mikraj. Solat yang dilakukan sebelum israk dan mikraj adalah pada waktu pagi dan petang. Lihat lebih lanjut berhubung peristiwa pensyariatan solat lima waktu. Safi al-Raḥmān al-Mubārakfurī, alRāhịiq al-Makhtum (Riyāụ: Dār al-Salām, 2004)163. 
masyarakat muslim di Malaysia khususnya berkait dengan urusan ibadah.

Jika dilihat secara umum, peruntukan PKP tentang larangan solat jemaah dan Jumaat di masjid dan surau adalah selari dengan badan-badan fatwa dunia. Secara ringkasnya dapat dilihat dalam jadual di bawah:

Jadual 1: Ringkasan fatwa solat Jumaat dan jemaah di masjid dan surau

\begin{tabular}{|l|l|}
\hline Institusi/Badan Fatwa & \multicolumn{1}{|c|}{ Fatwa } \\
\hline Dār al-Iftā' & $\begin{array}{l}\text { Syariat Islam mengharuskan gugur solat Jumaat } \\
\text { dan solat jemaah di masjid dalam situasi wabak } \\
\text { untuk menjaga keselamatan dan mencegah } \\
\text { penularan wabak.* }\end{array}$ \\
\hline $\begin{array}{l}\text { Haiah Kibār al-Ulamā' bi } \\
\text { al-Azhar al-Sharīf }\end{array}$ & $\begin{array}{l}\text { Harus secara syarak untuk menghentikan solat } \\
\text { Jumaat dan jemaah dalam negara.** }\end{array}$ \\
\hline $\begin{array}{l}\text { Al-Ittihād al-'Alām̄̄̄ } \text { 'Ulāā al-Muslimīn } \\
\text { 'Ulatwa memberhentikan solat jemaah dan Jumaat } \\
\text { adalah bersandarkan kepada al-Quran dan al- } \\
\text { Sunnah, dan fatwa ini dikukuhkan dengan } \\
\text { kepentingan menjaga kesejahteraan nyawa } \\
\text { dalam agama Islam.*** }\end{array}$ \\
\hline $\begin{array}{l}\text { Haiah al-Iftā' fì Wizārah } \\
\text { al-Awqāf wa al-Shuūn al- } \\
\text { Islāmiah al-Kuwāyt }\end{array}$ & $\begin{array}{l}\text { Memberhentikan semua aktiviti solat jemaah } \\
\text { dan solat Jumaat di masjid.**** }\end{array}$ \\
\hline
\end{tabular}

* Shawqī Ibrāhim 'Allām, "Suqūt al-Jum'ah wa al-Jamā'ah bi Sabab Fairūs Kurūnā,” laman sesawang Dār al-Iftā’ al-Mișriyyah, dicapai pada 26 Mac 2020, https://cutt.ly/stTO0FZ.

** Aḥmad Ṭayyib, "Bayān Haiah Kibār al-'Ulamā bi Azhar al-Sharīf Hawl Firūs Kurūnā," laman sesawang Hapi Journal, dicapai pada 26 Mac 2020, https://cutt.ly/atTO8px.

*** Aḥmad al-Raysūn̄̄, "al-Raysūnī Yatahaddath 'an Dalāil Man' Șolāh al-Jamā’ah wa man Yad'a an Kurūnā Ghadab min Allah,” laman sesawang aljazeera.net, dicapai pada 26 Mac 2020, https:// cutt.ly/JtTO50e.

**** Wizārah al-Awqāe wa al-Shuūn al-Islāmiyyah, "Athār Qarār Wizārah al-Awqāf fi al-Kuwāyt Waqaf Șalāh al-Jum'ah wa alȘalāh fĩ al-Masājid, laman sesawang arabic.cnn.com, dicapai 24 April 2020, https://arabic.cnn.com/middle-east/article/2020/03/14/ kuwait-mosques-pray-mass-ban-social-reactions. 


\begin{tabular}{|l|l|}
\hline \multicolumn{1}{|c|}{ Institusi/Badan Fatwa } & \multicolumn{1}{|c|}{ Fatwa } \\
\hline $\begin{array}{l}\text { Al-Majma' al-Fiqhī al- } \\
\text { 'Irāqī }\end{array}$ & $\begin{array}{l}\text { Wajib beriltizam dengan pandangan pakar dan } \\
\text { meninggalkan setiap perhimpunan walaupun } \\
\text { untuk tujuan ibadah secara jemaah mahupun } \\
\text { selain ibadah.***** }\end{array}$ \\
\hline
\end{tabular}

Daripada fatwa-fatwa yang dibentangkan tersebut, dapat dilihat coraknya yang sama iaitu berlaku larangan solat Jumaat dan solat fardhu secara jemaah di masjid dan surau. Ini disebabkan ancaman mudarat terhadap nyawa melalui Covid-19 yang mudah merebak antara individu. Fatwa-fatwa ini secara tidak langsung menguatkan arahan PKP yang telah diwartakan di Malaysia.

Di samping itu, PKP yang diwartakan adalah daripada pemerintah (ulul amri) kepada para rakyat di mana ianya selari dengan bidang kuasa pemerintah yang perlu menjamin kemaslahatan rakyatnya. Lantaran itu, tindakan pemerintah dalam mengumumkan PKP adalah selaras dengan kaedah tașarruf alimām manuūt bi al-mașlahah. Bermakna, PKP perlu dipatuhi oleh seluruh rakyat Malaysia untuk mengkuarantinkan diri di kediaman serta tidak menjalankan himpunan di mana-mana premis termasuklah bagi tujuan ibadah di masjid. Kepatuhan rakyat di negara ini terhadap PKP adalah wajib berdasarkan firman Allah SWT:

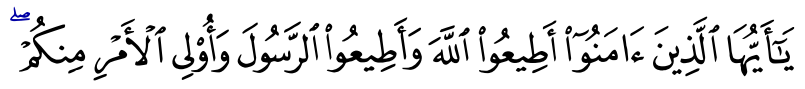

Terjemahan: "Wahai orang-orang yang beriman, taatlah kamu kepada Allah dan taatlah kamu kepada Rasul dan kepada orang-orang yang berkuasa dari antara kamu."

(Surah al-Nisā’, 4: 59)

Sungguhpun ayat tersebut membawa faham kepatuhan kepada pemimpin adalah wajib sebagaimana kewajipan taat kepada Allah

\footnotetext{
***** al-Majma' al-Fiqhī al-'Irāqīe "Fatwā bi Sha'ni Adā' al-Ibādāt al-Jamā'iyyah ma' Intishār Fairūs Kurunā," laman sesawang alMajma' al-Fiqhī al-'Irāqī li Kibār al-Ulamā'li al-Da'wah wa alIftā', dicapai 24 April 2020, https://cutt.ly/VtTPhSr.
} 
SWT dan RasulNya, namun ketaatan kepada pemimpin bukanlah bersifat mutlak dalam semua perkara. Hal ini kerana, pemimpin merupakan manusia yang tidak terlepas daripada kesilapan. Ini bermakna, para pemimpin tidak perlu ditaati dalam urusan kemaksiatan.

Sebaliknya, PKP bukanlah arahan yang menjurus kepada perkara kemaksiatan. Sungguhpun seolah-olah syiar agama dihalang daripada terus diimarahkan di masjid dan surau, namun ia bukanlah bersifat kekal dan mutlak. Malah, terdapat arahan agar masjid dan surau terus diimarahkan dalam kalangan para pentadbir. Di samping itu, PKP yang diperintahkan ini juga mempunyai satu tujuan yang jelas ke arah mengekang wabak Covid-19 di peringkat nasional. Hal ini adalah selari dengan dalil umum daripada nas al-Quran:

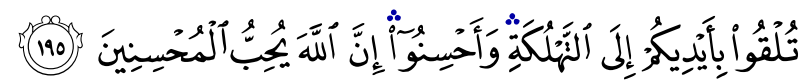

Terjemahan: “...Dan janganlah kamu menjatuhkan dirimu sendiri ke dalam kebinasaan, dan berbuat baiklah, kerana sesungguhnya Allah menyukai orang-orang yang berbuat baik."

(Surah al-Baqarah, 2: 195)

Daripada ayat ini, Allah SWT memerintahkan agar manusia menjauhi sebarang bentuk kehancuran dan malapetaka. Benar, menunaikan ibadat di masjid bukanlah termasuk dalam perkara yang menghancurkan diri, malah sebaliknya menjurus kejayaan yang hakiki di akhirat kelak. Namun begitu, dalam keadaan wabak Covid-19 yang sedang melanda negara, mereka yang berhimpun di rumah ibadat boleh dianggap mengundang malapetaka terhadap diri. Bukan sekadar itu, jemaah yang hadir mungkin turut mengancam para jemaah yang lain kerana menjadi pembawa Covid-19 dalam keadaan tidak sedar. Sedangkan, perbuatan ini لا ضرر terlarang dalam agama dan dapat difahami melalui kaedah

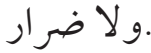

Di samping itu, peruntukan larangan solat Jumaat dan jemaah di masjid turut selari dengan beberapa hadis yang menjelaskan tindakan berhadapan dengan krisis wabak taun. Antaranya 
Rasulullah SAW memerintahkan para sahabat yang dijangkiti taun agar tidak keluar daripada rumahnya.

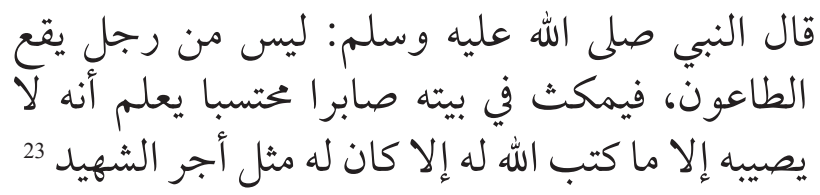

Terjemahan: "Nabi SAW telah bersabda: Bukanlah daripada seorang lelaki yang menghidap taun, dan ia kekal dirumahnya dalam keadaan sabar dan bermuhasabah bahawa tidak ditimpa kepadanya kecuali Allah SWT telah takdirkan, maka baginya ganjaran seperti pahala syahid."

Menghuraikan hadis tersebut, Ibn Hajar menegaskan bahawa ganjaran tersebut merangkumi mereka yang bersabar di atas ujian wabak yang melanda di sesuatu tempat yang didiami. Ganjaran yang sama iaitu pahala semisal syahid turut diperoleh sekiranya berada dalam keadaan sabar, muhasabah dan bertawakal kepada Allah SWT.

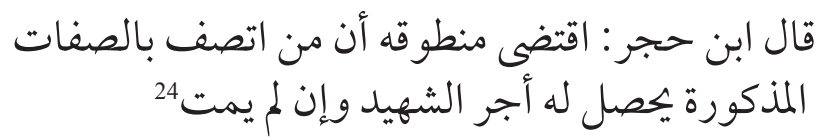

Terjemahan: "Ibn Hajar berkata: Secara mantuqnya hadis tersebut menunjukkan bahawa sesiapa yang bersifat dengan sifat-sifat yang disebutkan (sabar, muhasabah dan tawakal) ia akan beroleh ganjaran syahid sekalipun tidak mati." iaitu:

Daripada hadis tersebut, dapat dirumuskan tiga perkara penting

23 Abū 'Abd Allāh bin Muhammad bin Hanbal, Musnad al-Imām Ahmad bin Hanbal, ditahqiqkan oleh Shu'ayb al-Arna'ūt, Baqiyyah Musnad Șaḥābah al-Anșār, no. Hadith 26139, (Bayrūt: Mu'assasah al-Risālah, 2001), 43: 235.

24 Aḥmad bin 'Alī bin Ḥajr al-'Asqalānī, Fatḥ al-Bārī Sharḥ Șahịh alBukhārī, ditahqiqkan oleh Muḥammad Fu;ād 'Abd al-Bāqī, Bāb Ajr al-Șābir 'Alā al-Ṭā'ūn, (Bayrūt: Dār al-Ma'rifah, 1379), 10: 194. 
a) Mereka yang dijangkiti sebarang penyakit berjangkit perlu melakukan kuarantin diri agar tidak dijangkiti oleh masyarakat sekeliling dalam keadaan penuh sabar, muhasabah dan bertawakal untuk peroleh kesembuhan.

b) Mereka yang sihat juga perlu melakukan kuarantin di rumah dalam keadaan sabar, muhasabah atas bencana dan bertawakal mengharapkan pulih musibah.

c) Mereka yang sihat dan sakit perlu menghindari aktiviti kemasyarakatan yang mengundang jangkitan dalam kalangan masyarakat

Sungguhpun hadis yang dibincangkan tidak memperincikan larangan untuk hadir berjemaah di masjid, namun hal tersebut dapat difahami secara mafhum hadis. Rumusan ini dapat dikuatkan lagi melalui tegahan Rasulullah SAW terhadap sesiapa yang makan makanan yang berbau lalu hadir ke tempat solat.

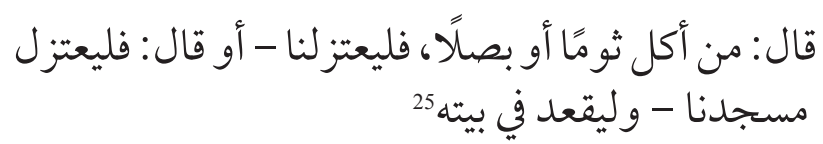

Terjemahan: "Barangsiapa yang makan bawang putih atau merah (yang tidak dimasak dan kuat baunya) maka jauhilah kami atau disebut: jauhilah masjidmasjid kami dan duduklah ia di rumahnya sahaja."

Larangan hadis ini mempunyai 'illah yang jelas sebagai alasan hukum. Justifikasi tegahan kerana perbuatan tersebut menimbulkan gangguan ke atas kekusyukan terhadap jemaah lain yang hadir. Bermakna, sudah tentu berlaku tegahan yang lebih kuat apabila terdapatnya ancaman yang lebih besar seperti Covid-19 kerana melibatkan keselamatan nyawa jemaah.

Sungguhpun begitu, hadis-hadis yang dibincangkan tersebut sama sekali tidak menegah golongan yang sihat untuk terus hadir

25 Muhammad bin Ismā‘īil al-Bukhārī, al-Jāmi` al-Musnad al-Ṣaḥị̣ alMukhtașar min Umūrī Rasūlillah SAW wa Sunanihi wa Ayyāmihi, ditahqiqkan oleh Muḥammad Zuhyar bin Nāṣir al-Nāṣir, Kitāb alAdhān, Bāb Mā Jā'a fī al-Thawm al-Nī wa al-Bașal wa al-Kirāth, no. Hadith 855, (Dār Ṭūq al-Najāh, 1422), 1: 170. 
ke masjid. Justeru, apakah asas PKP untuk melarang seluruh masyarakat Islam dari hadir ke masjid tanpa membezakan antara yang sihat dan sakit. Memperhalusi persoalan tersebut, Covid-19 boleh disifatkan sebagai satu bentuk keuzuran kepada mukallaf untuk menunaikan hukum taklif sepertimana keadaan biasa. Hal ini dapat difahami dengan berkesan melalui hadis yang mengisyaratkan supaya lafaz azan ditukar kepada șallu fi buyūtikum ketika hujan lebat melanda.

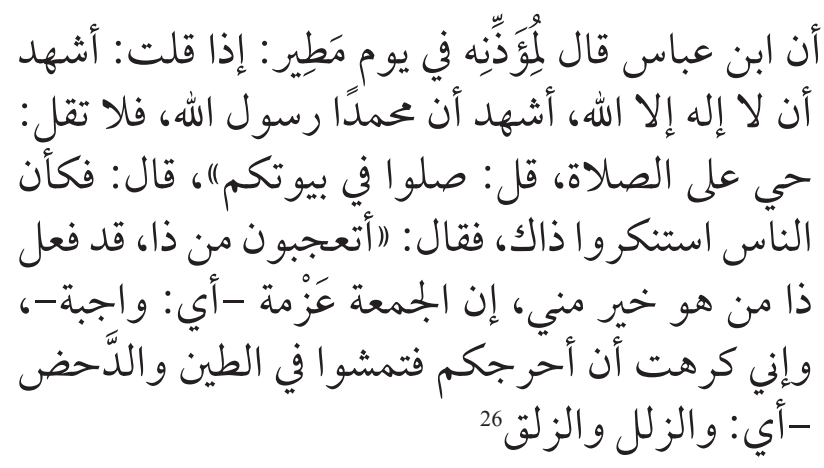

Terjemahan: "Dari Abdullah bin Abbas ra bahawa beliau telah berpesan kepada tukang azan ketika

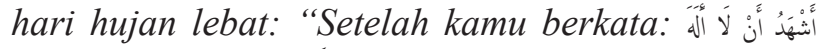

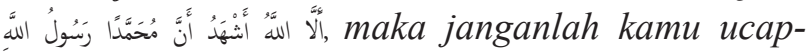

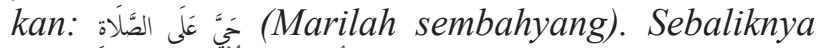

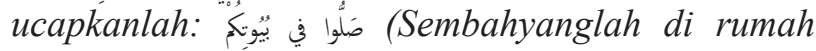
kamu). Beliau berkata: Orang ramai seolah-olah mengingkari perbuatan tersebut. Lalu Abdullah bin Abbas berkata: "Adakah kamu semua hairan dengan perbuatan ini sesungguhnya orang yang lebih mulia dariku (Rasulullah) telah mengajarkan perbuatan ini. Sesungguhnya sembahyang berjemaah itu wajib tetapi aku tidak mahu kamu keluar rumah dan kamu berjalan di atas tanah yang licin dan berlumpur."

26 Muslim bin al-Hajjāj, al-Musnad al-Ṣahịh al-Mukhtașar bi Naql al'Adl 'an al-'Adl ilā Rasūlillah SAW, ditahqiqkan oleh Muhammad Fu'ād 'Abd al-Bāqī, Kitāb al-Musāfirīn wa Qașriha, Bāb al-Șalāh fĩ al-Riḥal fì al-Mațar, no. Hadith 699, (Bayrūt: Dār Iḥyā’ al-Turāth al'Arabiy, t.t), 1: 485. 
Hadis tersebut menjelaskan keadaan hujan yang menyebabkan tiada lagi tuntutan untuk menunaikan solat jemaah di masjid. Ini menunjukkan, hujan merupakan salah satu bentuk keuzuran untuk membolehkan tiadanya solat jemaah di masjid. Bermakna, sekiranya terdapat keuzuran yang lebih dahsyat seperti Covid-19, sudah tentu lebih kuat larangan hadir ke masjid bagi mencegah penularan wabak dalam kalangan jemaah.

Justeru, larangan hadir ke masjid untuk menunaikan solat Jumaat mahupun solat fardu secara jemaah adalah disebabkan keuzuran yang dibenarkan syariat. Sungguhpun Covid-19 tidak disebutkan sebagai satu bentuk keuzuran, namun ia tergolong dalam bentuk penyakit yang mewujudkan keuzuran. Malah, syariat juga melarang sebarang bentuk mudarat samada kepada diri sendiri mahupun kepada pihak lain. Dalam hal ini, adalah jelas Covid-19 termasuk dalam satu bentuk mudarat yang perlu dijauhi. Lantaran itu, peruntukan PKP yang berkait larangan solat Jumaat dan fardu secara jemaah di masjid adalah bertepatan dengan syariat Islam yang mencegah sebarang mudarat kepada agama, nyawa, akal, keturunan dan harta.

\section{ANALISIS LARANGAN SOLAT JUMAAT DAN SOLAT JEMAAH DALAM PKP BERASASKAN PARAMETER MAQĀSID AL-SHARI'AH}

Parameter maqūșid al-sharī'ah telah dibahaskan oleh para ulama bertujuan memastikan mașlahah sebenar dapat dihasilkan serta tidak bercanggah dengan mașlahah yang lebih kuat di samping memastikan kehadiran mașlahah benar-benar terhasil ketika berlakunya pertembungan antara mașlahah dan mafasadah. Parameter maqāṣid al-sharī'ah ini penting kerana mașlahah memiliki urutannya yang pelbagai. Ini dapat dibuktikan melalui hadis antaranya;

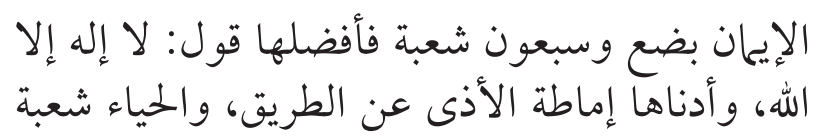




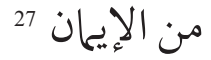

Terjemahan: "Iman mempunyai 70 cabang. Paling tinggi adalah mengucap la ilaha illa Allah, dan paling rendah adalah membersihkan perkara yang menyakitkan daripada jalan. Dan malu juga satu cabang daripada iman."

Daripada hadis ini, maṣlahah yang terkandung dalam agama mempunyai tingkatan yang berbeza di mana mașlahah tertinggi adalah dengan ucapan syahadah dan mașlahah terendah terkandung dalam perbuatan membuang sesuatu yang menyakitkan dari jalanan. ${ }^{28}$ Malah, perbezaan tersebut juga menjadi faktor perbezaan dalam bab ketaatan seperti yang ditegaskan oleh 'Izz al-Dīn 'Abd al-Salām.

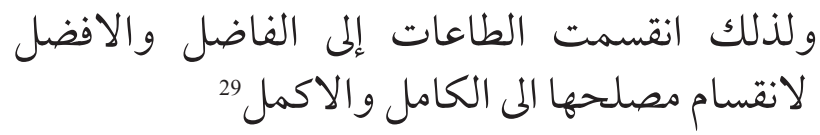

Terjemahan: "Oleh yang demikian, perkara ketaatan dikategorikan kepada yang baik dan yang terbaik berdasarkan pembahagian mașlahahnya kepada yang sempurna dan yang lebih sempurna."

Disebabkan terdapat perbezaan tersebut, maka para ulama telah meletakkan sebuah parameter untuk melakukan pentarjihan antara mașālih. Secara ringkas, parameter tersebut terdapat dalam pembahagian ulama usul melalui wacana maqāșid dan mașālih kepada tiga peringkat (al-darūriyyāt, al-hājiyyāt dan altahsiniyyāt), pembahagian mașālih kepada umum dan khusus,

27 Muslim bin al-Hajjāj, al-Musnad al-Șaḥị al-Mukhtașar bi Naql al'Adl 'an al-'Adl ilā Rasulillah SAW, ditahqiqkan oleh Muhammad Fu'ād 'Abd al-Bāqī, Kitab al-Īmān, Bāb Shu'ab al-Īmān, no. Hadith 35, (Bayrūt: Dār Ihỵā’ al-Turāth al-'Arabiy, t.t), 1: 63.

28 Muhammad Sa'̄̄d Ramaḍān al-Būṭ̂̄, Dawābiṭ al-Maṣlahah fì alSharì'ah al-Islāmiyyah (Dimashq: Muassasah al-Risālah, 1973), 255.

29 Muhammad 'Izz al-Dīn 'Abd al-'Azīz Ibn 'Abd al-Salām, Qawā'id al-Aḥkām fì Mașāliḥ al-Anām, ed. Taha 'Abd al-Ra'uf Sa'ad (alQāhirah: Maktabah al-Kulliyah al-Azhariyyah, 1991), 1:22-23 
kulliyāt dan juziyyāt serta pembahagian al-darūriyyāt kepada lima kulliyāt. ${ }^{30}$

Lebih terperinci lagi, kajian mendapati satu parameter maqāssid al-sharì'ah yang sistematik digariskan oleh al-Būṭi melalui wacana maqāsșid al-sharī'ah tokoh ini.

\section{Menilai al-Mașlahah al-Khamsah Berdasarkan Tertibnya}

Susunan mașlahah al-khamsah tersebut disokong oleh petunjuk analisis terhadap seluruh hukum juziyyāt. Dalam hal ini, mendahulukan agama berbanding nyawa disandarkan melalui hukum jihad. Mengutamakan nyawa terhadap akal dapat difahami daripada hukum keharusan minum minuman yang memabukkan sewaktu darurat. Melalui ijmak, disyaratkan pesalah hukuman zina dihukum tanpa merosakkan pancainderanya dan kekuatan akalnya. Ia membuktikan syarak mengutamakan maqāșid akal berbanding keturunan. Syarak turut melarang keras perbuatan zina bagi tujuan mencari pendapatan di mana memberi petunjuk bahawa keturunan lebih utama daripada harta. ${ }^{31}$

\section{Menilai al-Mașālih berdasarkan Tiga Tahap, iaitu al- Darūriyyāt, al-Hājiyyāt dan al-Tahsiniyyāt}

Berdasarkan kriteria ini, al-Būṭ̂̄ menegaskan bahawa mașlahah yang berada pada tahap al-darüriyyāt lebih diutamakan berbanding al-mașlahah al-hajiyyat ketika bertembung antara kedua-duanya. Begitu juga keadaanya jika berlaku pertembungan antara almașlahah al-hājiyyāt dan al-mașlaḥah al-tahsiniyyāt, perlu diraikan al-mașlahah al-hajiyyāt. Misalnya hukum menunaikan solat dibelakang imam yang fasik adalah harus. Ini kerana, solat jemaah mengandungi al-mașlahah al-hâjjiyyāt sedangkan sifat fasik itu termasuk dalam al-mașlahah al-tahsiniyyāt yang ada kaitannya dengan adab dan akhlak. Keharusan tersebut kerana mentarjihkan al-mașlaḥah al-hājiyyāt iaitu menghidupkan syiar

$30 \quad$ Aḥmad al-Raysūnī, al-Tajdīd al-Ușūlī Naḥwā Siyāghah Tajdīdiyyah lì 'Ilm Ușūl al-Fiqh (Herndon: al-Ma'had al-'Ālamī li Fikr al-Islāmī, 2014), 416.

31 Al-Būṭī, Dawābiṭ al-Maṣlaḥah, 261. 
Islam dengan solat berjemaah ke atas al-maṣlahah al-tahsiniyyāt. ${ }^{32}$

\section{Menilai Tahap Shumūliyah al-Mașālih}

Sekiranya berlaku pertembungan antara mașālị̣ dalam kullī yang sama sebagai contoh al-dìn, maka pada ketika itu pertimbangan akan beralih dengan melihat tahap cakupan mașlahah yang dibawa melibatkan pertimbangan antara mașlaḥah individu dan kumpulan, perkara-perkara fardu dan sunat dan seumpamanya. Misalnya kesibukan mengajar perkara-perkara asas agama lebih diutamakan berbanding mengajar perkara-perkara sunat dalam urusan agama. ${ }^{33}$

\section{Menilai Pencapaian antara Maṣlahah dan Mafsadah}

Prinsip ini terdedah kepada kemungkinan yang pelbagai kerana ia terdiri daripada al-mașlaḥah al-räjiḥah dan al-mașlaḥah almashkükah atau al-mașlaḥah al-mawhümah. Misalnya, penjualan senjata kepada pihak musuh di musim peperangan merupakan almafsadah al-räjihah. ${ }^{34}$ Realitinya, akan berlaku kesukaran untuk menerapkan mașlahah sebenar dalam kes-kes baru berdasarkan prinsip ini. Ianya dapat difahami dalam kata-kata Ibn Daqīq al-' Id yang dinaqalkan al-Shawkānī;

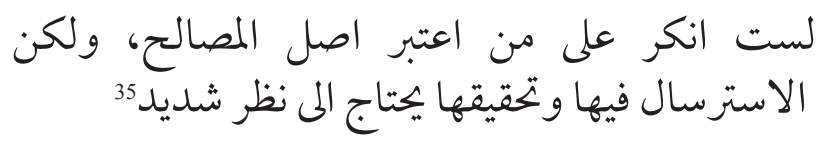

Terjemahan: "Aku tidak mengingkari terhadap sesiapa yang mengiktiraf usul al-mașāliḥ, akan tetapi untuk merealisasikan mașlahah daripada usul ini memerlukan penelitian yang rapi."

\footnotetext{
$32 \quad$ Ibid., 251.

33 Ibid., 253.

34 Ibid., 254.

35 Muhammad 'Alī al-Shawkānī, Irshād al-Fuhūl ilā Tahqūq al-Haq min 'Ilm al-Uṣūl, ed. Abū Hafs Sami (al-Riyaḍ: Dār al-Faḍīlah, 2000), 2:994.
} 
Hal ini kerana, hakikat mașlahah dan mafsadah itu sentiasa wujud dalam sesuatu isu sehingga boleh disimpulkan tiada sesuatu mașlahah yang sunyi daripada mafsadah dan tiada mafsadah yang sunyi daripada mașlahah. Perkara ini lebih awal ditegaskan oleh al-Raysūnī: ${ }^{36}$

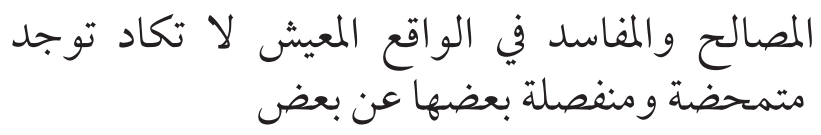

Terjemahan: "Keluruhan mașāilh dan mafāsid dalam kehidupan manusia hampir tidak berpisah antara satu dengan yang lain."

Fakta ini lebih mudah difahami dengan melihat kepada contoh pensyariatan hukum Islam seperti dalam larangan minum arak di mana pada minuman tersebut ada manfaat dan mafsadah akan tetapi mafsadahnya lebih besar dan perlu diharamkan bagi mendatangakn mașlaḥah penjagaan akal.

Kembali kepada isu larangan solat jemaah di bawah peruntukan PKP di mana kedudukan solat jemaah sekalipun mempunyai hukum yang berbeza menurut pandangan mazhab-mazhab di mana antaranya wajib dan sunat, namun dari dimensi mașāith amalan ini berada pada tahap yang sama. Hal ini kerana, hubungan antara hukum taklīfì dan maqāșid al-sharī'ah bukan berbentuk shaklī iaitu wajib dan haram berada dalam kategori al-darūriyyāt, sunat dan makruh berada dalam kategori al-hājiyyāt serta harus berada dalam kategori al-tahsiniyyāt. Ini bermakna, hukum-hukum taklïfi mengisi setiap peringkat al-mașālih kerana dihubungkan antara kedua-duanya dengan bentuk al-maw $d \bar{u}$ ' $\bar{l}$ di mana menilai kepada mașlahah mafsadah dalam hukum taklīfi tersebut. ${ }^{37}$

Oleh kerana itu, satu persoalan perlu ditimbulkan bagi menilai kewajaran larangannya ketika PKP di mana adakah hifz al-din akan ternafi mahupun musnah tanpa adanya solat jemaah di masjid mahupun surau? Atau adakah umat Islam akan berada dalam kesukaran akibat tidak dapat melakukan amalan solat jemaah yang lebih menepati konsep al-ḥajjiyyāt? Menjawab

\footnotetext{
36 Al-Raysūnī, al-Tajd̄̄d al-Ușūlī, 414.

37 Jamāl al-Dīn 'Aṭiyyah, Naḥwā Taf' '̄l Maqāṣid al-Sharī'ah (Dimashq:

Dār al-Fikr, 2001), 70.
} 
persoalan tersebut, perlu dijelaskan bahawa kedudukan solat jemaah adalah sebahagian daripada syiar untuk memelihara agama (hifz al-dīn) di peringkat al-hājiyyāt sekalipun dari segi taklifnya para ulama berbeza pandangan. Ini kerana, hifz al-dīn di peringkat al-darūriyyāt bermaksud mendirikan rukun-rukun Islam $^{38}$ seperti mengucap kalimah syahadah, berpuasa, solat fardu dan semisalnya. ${ }^{39}$ Sementara, solat jemaah merupakan satu kaedah melaksanakan tuntutan salah satu rukun Islam yang darūri iaitu solat. Justeru, kedudukan solat jemaah adalah sebahagian alhạjiyyāt bagi menjaga objektif agama. Dalam hal ini, al-Raysūnī turut menegaskan bahawa solat jemaah merupakan pelengkap (mukammil) dalam usaha memelihara agama. ${ }^{40}$ Bermakna, sekiranya kedudukan ibadah ini bersifat penyempurna dalam memelihara maqāșid agama, maka pada keadaan tertentu sudah tentu boleh ditangguhkan demi merealisasikan maqāṣid yang lebih penting diperingkat al-darūriyyāt.

Dalam hal ini, maka jelaslah kedudukan solat jemaah termasuk dalam kategori al-hājiyyāt untuk merealisasikan mașlaḥah agama. Namun begitu, perlu difahami juga bahawa kefarduan ibadat solat itu sendiri termasuk dalam urusan al-ḍarūriyyāt untuk memelihara mașlaḥah agama ${ }^{41}$ Sekiranya kedudukan solat itu sendiri adalah al-darūriyyāt, maka hal ini lebih menguatkan lagi hujah untuk menggugurkan perlaksanaannya secara jemaah di masjid kerana amal jemaah dalam mengerjakan ibadah ini ialah al-hājiyyāt. Bermaksud, sesuatu yang berada di tahap al-darüriyyāt pasti tidak dapat digugurkan dalam sebarang keadaan sekalipun. Lantaran itu, ibadah solat tidak terkecuali kepada mereka yang bermusafir mahupun berada dalam kesulitan yang dahsyat sekalipun kerana kedudukannya yang darūrī dalam menjaga agama.

\footnotetext{
38 Al-Būṭī, Dawābit al-Maṣlaḥah, 119.

39 Abū Isḥāq Ibrāhīm bin Mūsā bin Muhammad al-Lukhmī al-Shātibī, al-Muwāfaqāt, ed. Abū 'Ubaidah Mashūr bin Hasan 'Alī Salmān (Saudi: Dār Ibn 'Affān, 1997), 2:18-19.

40 Aḥmad al-Raysūnī, “al-Raysūnī Yatahaddath 'an Dalāil Man' Șolāh al-Jamā'ah wa man Yad'a an Kurūnā Ghadab min Allah," laman sesawang aljazeera.net, dicapai pada 26 Mac 2020, https://cutt.ly/ JtTO50e.

41 Al-Būṭī, Dawābiṭ al-Maṣlaḥah, 251.
} 
Selain itu, isu ini perlu dinilai berdasarkan ta'ārud antara mașālih supaya ianya lebih jelas. Hal ini kerana, PKP yang dilaksanakan mempunyai motif untuk memelihara nyawa manusia (hifz al-nafs). Sedangkan, dalam amalan solat jemaah mempunyai motif untuk memelihara mașlahah agama (hifz al-dinn). Oleh kerana itu, mașlahah manakah yang lebih utama dipelihara dan dijaga. Perlu dijelaskan, sungguhpun susunan al-kulliyāt al-khams adalah berbeza dalam wacana sarjana Islam, namun asasnya sebagaimana yang dinyatakan oleh al-Ghazāli ${ }^{42}$ dan kemudiannya diperincikan oleh al-Shātibī dengan hifž al-dīn, hifž al-nafs, hifz al- 'aql, hifz al-nasl dan hifz al-māl bersandarkan dalil istiqrā' ke atas syariah, ${ }^{43}$ namun perkara yang perlu dinilai dalam kes solat jemaah ini ialah keutamaan antara memelihara mașlaḥah agama dan mașlaḥah nyawa yang berada dalam tahapan mașālih yang berbeza.

Hal ini kerana, seolah-olah fatwa-fatwa yang dikeluarkan dalam isu ini mengutamakan pemeliharaan nyawa sekali gus mengabaikan mașlahah agama. Sungguhpun secara pengamatan kasar begitu, namun perlu ditegaskan bahawa kedudukan solat jemaah yang mempunyai mașlahah agama bukan satu amalan agama yang bersifat al-darūriyyāt. Malah, seperti yang dijelaskan bahawa ibadat ini adalah penyempurna atau diistilahkan alhăjiyyāt dalam memelihara agama ${ }^{44}$ Lantaran itu, apabila berlaku pertembungan antara mașlahah agama di peringkat al-hājiyyāt dengan mașlahah nyawa di peringkat al-darūriyyāt, maka perlu didahulukan pencapai maṣlahah nyawa. Ini bermaksud, pemeliharaan mașlahah nyawa untuk mengelak penularan Covid-19 dalam kalangan jemaah menjadi satu pertimbangan

42 'Ațiyyah, Naḥwā Taf'

43 Al-Shātịī̄,al-Muwāfaqāt, 2:32.

"Sekiranya dihilangkan (penjagaan) agama pasti akan hilang balasan yang diharapkan (dalam melaksanakan tuntutan syariah), sekiranya dihilangkan (pemeliharaan) mukallaf (nyawa) pasti akan hilang orang yang hendak mengamalkan agama, kalau dihilangkan (penjagaan) akal pasti akan hilang orang yang datang kepada agama, sekiranya diabaikan keturunan maka adat tidak boleh kekal, jika diabaikan harta kehidupan tidak akan kekal."

44 Fahmī Muhammad 'Ulwān, al-Qiyām wa Maqāșid al-Tashrī' alIslāmī, (t.t: t.tp, 1989), 41. 
yang lebih utama. Perlu ditegaskan, hal ini bukanlah ramalan semata-mata. Ini kerana, kes kluster pertama Covid-19 di Malaysia adalah berpunca daripada aktiviti keagamaan di Masjid Sri Petaling dalam kalangan jemaah. Bukanlah bermakna mereka yang terlibat boleh dihukum dengan tohmahan dan caci maki oleh masyarakat seperti yang ditegaskan kerajaan, ${ }^{45}$ namun kejadian ini membuktikan perlunya mașlahah nyawa diutamakan berbanding mașlahah agama yang bersifat al-hājiyyāt kerana Covid-19 boleh berjangkit tanpa mengira tempat, masa dan individu.

Membahaskan arahan yang termaktub dalam PKP melibatkan urusan keagamaan, timbul persoalan mengapa tidak dihadkan larangan kepada penghidap Covid-19 semata-mata. Malah hal ini mungkin lebih menepati kaedah fekah yang menyebutkan . Hal ini secara dasarnya tidak dinafikan. Buktinya dapat dilihat dalam fatwa seperti Wilayah Persekutuan yang menggariskan dua situasi iaitu sekiranya keadaan wabak terkawal, mereka yang berpenyakit sahaja dilarang untuk mengunjungi masjid dan surau. ${ }^{46}$ Namun begitu, tetap timbul kemungkinan penularan Covid-19 antara jemaah. Kemungkinan (ihtimāl) ini dibina atas beberapa asas yang jelas antaranya:

a) Terdapat masyarakat yang tidak jujur apabila mereka yang telah menghidap Covid-19 tidak mengkuarantin diri serta terus menjalani kehidupan bermasyarakat seperti biasa. ${ }^{47}$ Sungguhpun kes-kes tidak jujur ini kebanyakannya dilaporkan

$45 \quad$ Tuan Buqhairah Tuan Muhamad Adnan, "Dr Noor Hisham Rayu Jangan Salahkan Tabligh," laman sesawang Sinar Harian, dicapai pada 27 Mac 2020, https://cutt.ly/NtTPm1r.

46 Zulkifli Mohamad al-Bakri, "Al-Kafi \#1657: Hukum Solat Jumaat Dalam Suasana Covid-19," laman sesawang Pejabat Mufti Wilayah Persekutuan, dicapai 3 Mei 2020, https://muftiwp.gov.my/artikel/ al-kafi-li-al-fatawi/4318-al-kafi-1657-hukum-solat-jumaat-dalamsuasana-covid-19.

47 Suzalina Halid, "Sikap Rakyat Tentukan Nasib COVID-19 di Malaysia," laman sesawang BHOnline, dicapai pada 28 Mac 2020, https://cutt.ly/ztTPI0a. 
di klinik dan hospital, ${ }^{48}$ namun tetap ada kemungkinan untuk berlaku di tempat ibadat. Bahkan, terdapat laporan pelanggaran PKP dalam kalangan rakyat yang sihat mahupun telah dijangkiti. ${ }^{49}$ Berdasarkan senario tersebut, dapat dibentuk zan yang rajih dan kuat untuk penyakit ini menular dalam kalangan jemaah kerana adanya jemaah yang tidak bersikap jujur dan telus.

b) Hayat virus ini turut menjadi asas dalam perintah kuarantin dalam kalangan seluruh masyarakat sihat mahupun tidak sihat. Seperti yang telah disebutkan di awal kajian ini, Covid-19 merupakan satu virus yang mampu kekal di udara melebihi 2 jam, di logam dan besi lebih 8 jam selain ianya dapat disebarkan melalui sentuhan, batuk dan bersin. Fakta-fakta ini menonjolkan terdapatnya ancaman untuk masyarakat Muslim terus berada di luar sekalipun dengan tujuan mengimarahkan masjid.

c) Menurut laporan perubatan, sebanyak $20 \%$ daripada populasi yang dijangkiti Covid-19 adalah tidak menunjukkan gejala (symptom-free). ${ }^{50}$ Situasi yang berlaku di Malaysia pula, pesakit Covid-19 tidak bergejala ini kira-kira 50.2\% daripada jumlah pesakit keseluruhan. ${ }^{51}$ Malah, lebih membimbangkan

48 Noor Hisham Abdullah, "37 petugas Hospital Teluk Intan positif Covid-19," laman sesawang myMetro, dicapai pada 29 Mac 2020, https://www.hmetro.com.my/mutakhir/2020/03/558509/37-petugashospital-teluk-intan-positif-covid-19-metrotv.

49 Media Baharu, "Tiga Kontak Rapat Pesakit COVID-19 Gagal Patuhi Perintah Kuarantin Di Rumah," laman sesawang Berita RTM, dicapai pada 28 Mac 2020, https://cutt.ly/vtTApzP.

50 George Citroner, " $20 \%$ of Coronavirus Infections Are symptomatic but Still Contagious," laman sesawang healthline, dicapai 12 November 2020, https://www.healthline.com/health-news/20percent-of-people-with-covid-19-are-asymptomatic-but-can-spreadthe-disease\#Only-20\%-remained-asymptomatic.

51 Tuan Bughairah Tuan Muhamad Adnan, "Covid-19: Satu daripada dua pesakit tidak bergejala," laman sesawang Sinar Harian, dicapai 12 November 2020, https://www.sinarharian.com.my/article/106415/ KHAS/Koronavirus/Covid-19-Satu-daripada-dua-pesakit-tidakbergejala. 
jika diperhatikan kepada jumlah sebenar kes tidak bergejala yang dilaporkan oleh Kementerian Kesihatan Malaysia setakat 8 Julai 2020 iaitu 6092 kes berbanding 8674 kes Covid-19 di Malaysia adalah tidak bergejala. ${ }^{52}$ Hal ini menunjukkan bahawa perlunya kepada usaha pencegahan yang sistematik melalui penjarakan sosial dan penjagaan kebersihan diri. Usaha ini sudah tentu dapat direalisasikan dengan tawaquf aktiviti di masjid dan surau serta tempat-tempat awam lain dalam tempoh tertentu sehingga usaha kawalan penularan Covid-19 diwujudkan.

Berdasarkan tiga asas yang dijelaskan, maka kaedah الضرورة تقدر بقدرها tidak terpakai untuk mengharuskan masyarakat muslim yang sihat untuk melakukan aktiviti solat jemaah dan solat Jumaat seperti keadaan biasa. Malah, semua pihak perlu dikuarantinkan kerana tindakan ini berorentasikan pencegahan. Daripada perspektif maqāșid al-shar'̄'ah, mereka yang sihat boleh disifatkan dalam situasi hajat untuk menunaikan solat jemaah di masjid. Oleh kerana Covid-19 mudah merebak, maka dalam situasi ini semua masyarakat yang belum berjangkit turut ditegah daripada berhimpun di masjid untuk apa sekalipun tujuannya. Hal ini menepati kaedah الحاجة تنزل منزة الضرورة di mana masyarakat muslim yang sihat termasuk dalam situasi darurat untuk memelihara kesihatannya. Ini terbukti melalui penegasan Shaykh al-Daddū dalam fatwanya bahawa halangan solat Jumaat dan jemaah adalah disebabkan situasi darurah dan hajah yang melanda masyarakat. ${ }^{54}$

52 Rafidah Mat Ruzki dan Noor Atiqah Sulaiman, "COVID-19: Saringan bersasar kesan pesakit tidak bergejala," laman sesawang BH Online, dicapai 12 November 2020, https://www.bharian.com. my/berita/nasional/2020/07/708742/covid-19-saringan-bersasarkesan-pesakit-tidak bergejala.

53 Jalāl al-Dīn 'Abd al-Raḥmān al-Suyūṭ̣̂, al-Ashbāh wa al-Nazāìr fì Qawā'id wa Furū' al-Shāfí̀'iyyah, ed. Muhammad Muhammad Tamīr dan Hāfiz 'Āshūr Ḥāfìz, ed. Ke-4 (al-Qāhirah: Dār al-Salām, 2009), 1:218.

54 Muhammad Hassan al-Daddū al-Shanqīṭị, "Munāqasāt li Rudud Ba'ḍ al-'Ulamā al-Fadillā' allātī Tafaḍ̣alu 'alaynā Bihā,' laman sesawang Facebook Muhammad Hassan al-Dadd̄̄ al-Shanqīțì, dicapai pada 30 Mac 2020, https://www.facebook.com/126668510695444/posts/ $3314289185266678 /$ ?sfnsn=mo. 
Dari satu sudut yang lain, aktiviti solat jemaah berdasarkan PKP ini tidak terhalang secara mutlak. Hal ini kerana, solat secara berjemaah masih dapat ditunaikan di rumah bersama ahli keluarga. Bermakna, darurat kepada nyawa ditangani tanpa mengabaikan bentuk ibadat secara jama'i secara mutlak kerana masih dapat ditunaikan bersama ahli keluarga. Jika dinilai الضرر يدفع dan الضرورة تقدر بقدرها keadaan ini, ianya selari dengan kaedah بقدر الإمكان Malah, sama sekali tidak mendatangkan kemudaratan dalam kalangan masyarakat ketika mana ibadah ini ditunaikan di kediaman masing-masing. Keadaan ini adalah bertepatan dengan kaedah fekah yang menyebutkan lā darar wa lā dirār dalam usaha mencegah penularan Covid-19.

Larangan terhadap segala aktiviti agama di masjid dan surau juga dilarang berdasarkan prinsip 'itibār al-maālāt. Secara umumnya, prinsip ini menggariskan panduan untuk menilai pencapaian di sebalik sesuatu keputusan fatwa dan ijtihad. Dalam isu wabak Covid-19, fakta perubatan membuktikan kadar jangkitan yang tinggi. Ini menunjukkan penularan wabak Covid-19 berlaku dengan mudah. Berdasarkan realiti ini, dapat dinilai implikasi akan datang ('itibār al-maāl) sekiranya tiada larangan aktiviti solat jemaah dan Jumaat di masjid iaitu pasti berlaku penularan Covid-19 dalam kalangan jemaah. Berdasarkan prinsip tersebut, maka pencapaian mașlahah melalui kegiatan agama ditunda untuk menghindari dari sebarang malapetaka di mana bersesuaian dengan kaedah 55 5رء المفاسد اولى من جلب المصالخ

Dari satu sudut yang lain, pematuhan masyarakat Islam yang merupakan majoriti penduduk di Malaysia terhadap PKP dapat diteladani oleh masyarakat berbilang agama. Umum mengetahui 68.6\% daripada masyarakat di Malaysia merupakan bumiputera di mana sinonim dengan Islam sebagai agama. ${ }^{56}$ Ini menunjukkan bahawa pentingnya ibadat ini ditunaikan di masjid dan surau demi mengangkat syiar agama pada setiap masa. Namun begitu, dalam situasi wabak Covid-19 mașlahah ini dianggap sebagai mașlahah khașsah kerana hanya mencakupi umat Islam. Bahkan, sekiranya

\footnotetext{
55 'Abd al-'Azīz Muḥammad 'Azzām, al-Qawā'id al-Fiqhiyyah (alQāhirah: Dār al-Ḥadith, 2005), 145.

56 Jabatan Penerangan Negara, "Demografi Penduduk," laman sesawang MyGoverment, dicapai pada 1 Mei 2020, https://www. malaysia.gov.my/portal/content $/ 30114$ ?language $=\mathrm{my}$.
} 
ibadat seperti solat Jumaat masih lagi diharuskan, maka bagaimana pula dengan masyarakat beragama Hindu, Buddha, Kristian dan sebagainya yang turut memiliki ibadat tersendiri. Adakah tidak akan berlaku tuntutan oleh masyarakat berbilang agama untuk melakukan hal yang sama? Benar, agama Islam amat menekankan aspek taharah dengan syariat wuduk dan tayamum ketika darurat sebagaimana firman Allah SWT:

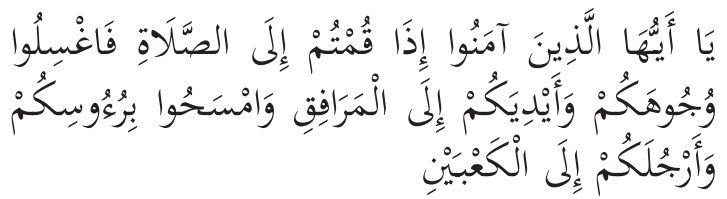

Terjemahan: "Wahai orang-orang yang beriman, apabila kamu hendak mengerjakan sembahyang (padahal kamu berhadas kecil), maka (berwuduklah) iaitu basuhlah muka kamu, dan kedua belah tangan kamu meliputi siku, dan sapulah sebahagian dari kepala kamu, dan basuhlah kedua belah kaki kamu meliputi buku lali."

(Surah al-Māidah, 5: 6)

Ayat di atas membahaskan tentang pensyariatan taharah melalui wuduk mahupun tayamum sebagai syarat sah ibadat solat yang ingin dilaksanakan. Namun begitu, keharusan ibadat dalam situasi wabak Covid-19 secara khusus dalam kalangan umat Islam dianggap sebagai mașlahah khașsah dibandingkan dengan mașlahah 'ämmah jika dilihat secara makro yang meliputi keselamatan dan keamanan seluruh rakyat di Malaysia. Maka, larangan PKP terhadap ibadah di masjid adalah selari dengan kaedah fekah yang menyebutkan al-mașlaḥah المصلحة العامة مقدمة على الخاصة. Dari satu sisi yang lain pula, penjagaan maslahah khassah hakikatnya melengkapi pemeliharaan maslahah 'ammah. Bermakna, tawaquf ibadat seketika dalam kalangan umat Islam adalah bertujuan merealisasikan maslahah 'ammah melibatkan kesejahteraan, kebajikan dan kesihatan rakyat Malaysia secara umum.

Sungguhpun secara keseluruhan kajian membuktikan bahawa larangan aktiviti jemaah di masjid adalah selari dengan maqasid 
al-shari'ah, namun perlu ditegaskan bahawa larangan ini perlu dinilai dari semasa. Ini kerana, dalam dunia komunikasi yang semakin moden pihak berkuasa juga perlu menimbang larangan ini dengan lebih terperinci bergantung kepada zon. Contohnya, kawasan hulu yang terpisah dari masyarakat luar tentunya tidak ada sebarang masalah utk melaksanakan solat jumaat dengan prosedur tertentu seperti dihadkan bilangan jemaah serta hanya melibatkan rumah sekitar masjid sahaja.

\section{KESIMPULAN}

Ibadat solat jemaah dalam Islam merupakan satu syiar yang bertujuan memelihara agama (hifz al-dīn). Sungguhpun begitu, ia tidak dapat dilaksanakan pada waktu tertentu misalnya fatrah wabak Covid-19. Hal ini tidak bermaksud, agama tidak lagi dipelihara di saat kritikal seperti ini. Malah, tidak beerti nyawa diutamakan secara mutlak dibandingkan dengan agama. Benar, tertonjol aspek yang sedemikian sekiranya aspek maqāssid alshari' $a$ h tidak diperhalusi dalam PKP dan fatwa-fatwa berkaitan larangan solat Jumaat dan solat jemaah di masjid dan surau. Inilah yang menyebabkan keluarnya kenyataan yang tidak wajar seperti "kami lebih takutkan Allah SWT" demi meneruskan amalan ibadat di masjid seperti biasa. Justeru, kajian menyimpulkan beberapa dapatan penting dalam larangan solat jemaah di bawah PKP:

a) Ibadat solat jemaah merupakan persoalan al-hājiyyāt untuk pelihara agama (hifz al-din) di mana dalam situasi darurat seperti Covid-19, nyawa lebih utama dipelihara kerana termasuk dalam al-darūriyyāt.

b) Agama masih terpelihara melalui arahan untuk terus imarahkan masjid dalam kalangan pentadbir masjid tidak lebih dari 5 individu. Peruntukan ini bertepatan dengan الضرورة تقدر بقدرها dan

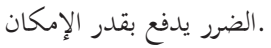

c) Umat Islam keseluruhannya diperintah kuarantin di rumah bagi mencegah penularan wabak Covid-19 dan hal ini selari dengan kaedah fekah درء المفاسد اولى من جلب المصالح.

d) Sungguhpun terdapat masyarakat yang sihat, namun tetap tidak dibenarkan masyarakat muslim berhimpun seperti biasa 
kerana wujudnya sikap tidak jujur dalam kalangan pesakit. Hal ini bertepatan dengan prinsip itibār al-maālāt daripada peristiwa yang dilaporkan sekali gus mendedahkan mudarat nyawa kepada jemaah.

e) Sekalipun syariat Islam amat menekankan aspek kebersihan dalam ibadat melalui wuduk, namun membenarkan masyarakat Islam terus beribadat seperti biasa akan menimbulkan percanggahan dengan kaedah المصلحة العامة مقدمة على الخاصة dalam realiti masyarakat majmuk di Malaysia untuk membendung wabak Covid-19.

f) Walau bagaimanapun, dari pelaksanaan PKP ini, pihak berkuatkuasa dicadangkan dari semasa untuk mengkaji dan memperhalusi aspek larangan ini dengan lebih terperinci seperti membezakan antara zon merah, zon kuning dan zon hijau, jenis aktiviti yang wajib dan yang sunat, jumlah kehadiran yang dibenarkan, kapasiti penduduk tempatan untuk melaksanakan SOP jika dibenarkan hadir ke masjid serta aspek-aspek lain agar larangan ini dapat ditarik balik secara berfasa dan demi meraikan juga kaedah الضرورة تقدر بقدرها.

\section{RUJUKAN}

'Abd al-'Azīz Muḥammad 'Azzām. al-Qawā'id al-Fiqhiyyah. alQāhirah: Dār al-Ḥadith, 2005.

Abū 'Abd Allāh bin Muhammad bin Hanbal. Musnad al-Imām Ahmad bin Hanbal. Bayrūt: Mu'assasah al-Risālah, 2001.

Abū Bakr al-Bayhaqī. Ma 'rifah al-Sunan wa al-Āthār. al-Qāhirah: Dār al-Wafā', 1991.

Abū Ishāak Ibrāhīm bin Mūsā bin Muhammad al-Lukhmī alShātibī. al-Muwāfaqāt. Ed. Abū 'Ubaidah Mashūr bin Ḥasan 'Alī Salmān. Saudi: Dār Ibn 'Affān, 1997.

Aḥmad al-Raysūnī. al-Raysūn̄̄ Yatahaddath 'an Dalāil Man' Solāh al-Jamā'ah wa man Yad'a an Kurūnā Ghadab min Allah, laman sesawang aljazeera.net, dicapai pada 26 Mac 2020, https://cutt.ly/JtTO50e.

Aḥmad al-Raysūnī. al-Tajdìd al-Ușūlì Naḥwā Siyāghah 
Tajdìdiyyah lī 'Ilm Ușūl al-Fiqh. Herndon: al-Ma'had al'Ālamī li Fikr al-Islāmī, 2014.

Aḥmad bin 'Alī bin Ḥajr al-'Asqalānī. Fath al-Bārī Sharh Ṣaḥịh al-Bukhārī. Bayrūt: Dār al-Ma'rifah, 1379.

Aḥmad Ṭayyib. Bayān Haiah Kibār al-'Ulamā bi Azhar al-Sharīf Hawl Firūs Kurūnā, laman sesawang Hapi Journal, dicapai pada 26 Mac 2020, https://cutt.ly/atTO8px.

al-Majma' al-Fiqhī al-'Irāqī. Fatwā bi Sha'ni Adā' al-Ibādāt alJamā'iyyah ma' Intishār Fairūs Kurunā, laman sesawang alMajma' al-Fiqhī al- 'Irāqī li Kibār al-Ulamā' li al-Da'wah wa al-Ifta ', dicapai 24 April 2020, https://cutt.ly/VtTPhSr.

Anthony Fauci. COVID-19: Ujian Pertama Vaksin Ke Atas Manusia Bermula Di AS, laman sesawang BHOnline, dicapai pada 24 April 2020, https://www.bharian.com.my/ dunia/amerika/2020/03/666859/covid-19-ujian-pertamavaksin-ke-atas-manusia-bermula-di.

Arsalan Khan. Why Pakistan isn't closing mosques despite the coronavirus threat, laman sesawang TRTWorld, dicapai pada 29 Mac 2020, https://www.trtworld.com/opinion/whypakistan-isn-t-closing-mosques-despite-the-coronavirusthreat-34913.

Berkeley Lovelace Jr., Noah Higgins-Dunn dan William Feuer. WHO considers 'airborne precautions' for medical staff after study shows coronavirus can survive in air, laman sesawang $C N B C$, dicapai pada 27 Mac 2020, https://www. cnbc.com/2020/03/16/who-considers-airborne-precautionsfor-medical-staff-after-study-shows-coronavirus-cansurvive-in-air.html.

Fahmī Muḥammad 'Ulwān. al-Qiyām wa Maqāṣid al-Tashrī' alIslāmì. t.t: t.tp, 1989.

Holly Secon, Lauren Frias dan Morgan McFall-Johnsen. A running list of countries that are on lockdown because of the coronavirus pandemic, laman sesawang Business Insider Malaysia, dicapai pada 24 Mac 2020, https://www. businessinsider.my/countries-on-lockdown-coronavirus- 
italy-2020-3? $\mathrm{r}=\mathrm{US} \& \mathrm{IR}=\mathrm{T}$,

George Citroner. 20\% of Coronavirus Infections Are symptomatic but Still Contagious, laman sesawang healthline, dicapai 12 November 2020, https://www.healthline.com/ health-news/20-percent-of-people-with-covid-19-areasymptomatic-but-can-spread-the-disease\#Only-20\%remained-asymptomatic.

Ibn 'Abd al-Bārr. al-Istidhkar. Beyrut: Dār Kutub 'Ilmiyyah, 2000. Jabatan Penerangan Negara. Demografi Penduduk, laman sesawang MyGoverment, dicapai pada 1 Mei 2020, https:// www.malaysia.gov.my/portal/content/30114? language $=$ my.

Jalāluddīn 'Abd al-Raḥmān al-Suyūṭi. al-Ashbāh wa al-Naẓāir fì Qawā'id wa Furū' al-Shâfí'iyyah, ed. Muhammad Muhammad Tamīr dan Hāfiż 'Āshūr Ḥāfizạ, ed. Ke-4. alQāhirah: Dār al-Salām, 2009.

Jamāl al-Dīn 'Ațiyyah. Naḥwā Taf'îl Maqāṣsid al-Sharī'ah. Dimashq: Dār al-Fikr, 2001.

Kimberly Hickok. What is a pandemic?, laman sesawang LiveScience, dicapai pada 26 Mac 2020, https://www. livescience.com/pandemic.html.

Matt Reynolds. What is coronavirus and what happens now it is a pandemic?, laman sesawang Wired, dicapai pada 25 Mac 2020, https://www.wired.co.uk/article/china-coronavirus.

Media Baharu. Tiga Kontak Rapat Pesakit COVID-19 Gagal Patuhi Perintah Kuarantin Di Rumah, laman sesawang Berita RTM, dicapai pada 28 Mac 2020, https://cutt.ly/ vtTApzP.

Muhammad 'Alī al-Shawkānī. Irshād al-Fuhūl ilā Tahqūq al-Haq min 'Ilm al-Ușūl, ed. Abū Ḥafs Sami. al-Riyaḍ: Dār alFaḍilah, 2000.

Muhammad 'Izz al-Dīn 'Abd al-'Azīz Ibn 'Abd al-Salām. Qawā 'id al-Aḥkām fì Mașāliḥ al-Anām, ed. Taha 'Abd al-Ra'uf Sa'ad. al-Qāhirah: Maktabah al-Kulliyah al-Azhariyyah, 1991.

Muḥammad al-Zuhaylī. al-Mu'tamad fì al-Fiqh al-Shāfi'i. Damsyik: Dār al-Qalam, 2011. 
Muḥammad bin Ismā‘īl al-Bukhārī. al-Jāmi ‘ al-Musnad al-Ṣaḥ̄h al-Mukhtașar min Umūrī Rasūlillah SAW wa Sunanihi wa Ayyāmihi. Dār Țūq al-Najāh, 1422.

Muḥammad Hassan al-Daddū al-Shanqīṭ̣̂. Munāqasāt li Rudud Ba'ḍ al-'Ulamā al-Fadillā' allātī Tafaḍḍalu 'alaynā Bihā, laman sesawang Facebook Muhammad Hassan al-Daddū al-Shanqūtī, dicapai pada 30 Mac 2020, https://www.facebook.com/126668510695444/ posts $/ 3314289185266678 /$ ?sfnsn=mo.

Muhammad Ibn Idrīs al-Shaāfi'̄̄. al-Umm. t:t : Dar al-Ma'rifah, 1393.

Muhammad Sa'īd Ramaḍān al-Būṭ̂̄. Dawābit al-Mașlahah fì alSharīah al-Islāmiyyah. Dimashq: Muassasah al-Risālah, 1973.

Muhyiddin Haji Muhammad Yassin. Perutusan Khas YAB Perdana Menteri Mengenai COVID-19 - 16 Mac 2020, laman sesawang Pejabat Perdana Menteri Malaysia, dicapai pada 27 Mac 2020, https://www.pmo.gov.my/ms/2020/03/ perutusan-khas-yab-perdana-menteri-mengenai-covid-1916-mac-2020-2/.

Muhyiddin Haji Muhammad Yassin. Perutusan Khas YAB Perdana Menteri Mengenai COVID-19 - 16 Mac 2020, laman sesawang Pejabat Perdana Menteri Malaysia, dicapai pada 27 Mac 2020, https://www.pmo.gov.my/ms/2020/03/ perutusan-khas-yab-perdana-menteri-mengenai-covid-1916-mac-2020-2/.

Muslim bin al-Hajjāj. al-Musnad al-Sahīh al-Mukhtașar bi Naql al- 'Adl 'an al-'Adl ilā Rasūlillah SAW. Bayrūt: Dār Ihyyā' al-Turāth al-'Arabiy, t.t.

Noor Hisham Abdullah. 37 petugas Hospital Teluk Intan positif Covid-19, laman sesawang myMetro, dicapai pada 29 Mac 2020, https://www.hmetro.com.my/ mutakhir/2020/03/558509/37-petugas-hospital-teluk-intanpositif-covid-19-metrotv. 
Noor Hisham Abdullah. Kenyataan Akhbar KPK 20 Mac 2020 -Situasi Semasa Jangkitan Penyakit Coronavirus 2019 (COVID-19) di Malaysia, laman sesawang DirectorGeneral of Health Malaysia, dicapai pada 27 Mac 2020, https://kpkesihatan.com/2020/03/20/kenyataan-akhbarkpk-20-mac-2020-situasi-semasa-jangkitan-penyakitcoronavirus-2019-covid-19-di-malaysia/.

Report coronavirus cases. Confirmed Cases and Deaths by Country, Territory, or Conveyance, laman sesawang Worldometer, dicapai pada 25 Mac 2020, https://www.worldometers.info/ coronavirus/\#countries.

Rafidah Mat Ruzki dan Noor Atiqah Sulaiman. COVID-19: Saringan bersasar kesan pesakit tidak bergejala, laman sesawang BH Online, dicapai 12 November 2020, https:// www.bharian.com.my/berita/nasional/2020/07/708742/ covid-19-saringan-bersasar-kesan-pesakit-tidak bergejala.

Ṣālị̣ Ibn Ghanim al-Sadlan. Șolāt al-Jamā'ah. Riyāḍ: Dār Balansiah, $1416 \mathrm{H}$.

Shawqī Ibrāhim 'Allām. Suqūt al-Jum'ah wa al-Jamā'ah bi Sabab Fairūs Kurūnā, laman sesawang Dār al-Iftā' al-Mișriyyah, dicapai pada 26 Mac 2020, https://cutt.ly/stTO0FZ.

Sinar Harian. Ribuan tabligh dari seluruh Asia berhimpun di Indonesia, laman sesawang Sinar Harian, dicapai pada 28 Mac 2020, https://www.sinarharian.com.my/article/74411/ KHAS/Koronavirus/Ribuan-tabligh-dari-seluruh-Asiaberhimpun-di-Indonesia.

Suzalina Halid. Sikap Rakyat Tentukan Nasib COVID-19 di Malaysia, laman sesawang BHOnline, dicapai pada $28 \mathrm{Mac}$ 2020, https://cutt.ly/ztTPI0a.

Tuan Buqhairah Tuan Muhamad Adnan. Dr Noor Hisham Rayu Jangan Salahkan Tabligh, laman sesawang Sinar Harian, dicapai pada 27 Mac 2020, https://cutt.ly/NtTPm1r.

Tuan Bughairah Tuan Muhamad Adnan. Covid-19: Satu daripada dua pesakit tidak bergejala, laman sesawang Sinar Harian, 
dicapai 12 November 2020, https://www.sinarharian.com. my/article/106415/KHAS/Koronavirus/Covid-19-Satudaripada-dua-pesakit-tidak-bergejala.

Wahbah al-Zuhaylī. Fiqh Islāmī wa Adillatuh. Damsyik: Dār alFikr, 1985.

Wizārah al-Awqāf wa al-Shuūn al-Islāmiyyah. Athār Qarār Wizārah al-Awqāf fi al-Kuwāyt Waqaf Șalāh al-Jum'ah wa al- Șalāh fĩ al-Masājid, laman sesawang arabic.cnn.com, dicapai 24 April 2020, https://arabic.cnn.com/middle-east/ article/2020/03/14/kuwait-mosques-pray-mass-ban-socialreactions.

World Health Organization. Rolling updates on coronavirus disease (COVID-19), laman sesawang World Health Organization, dicapai pada 27 Mac 2020, https://www.who. int/emergencies/diseases/novel-coronavirus-2019/eventsas-they-happen.

Zulkifli Mohamad al-Bakri. Al-Kafi \#1657: Hukum Solat Jumaat Dalam Suasana Covid-19, laman sesawang Pejabat Mufti Wilayah Persekutuan, dicapai 3 Mei 2020, https://muftiwp. gov.my/artikel/al-kafi-li-al-fatawi/4318-al-kafi-1657hukum-solat-jumaat-dalam-suasana-covid-19. 
Analisis Larangan Aktiviti Keagamaan di Masjid dalam Peruntukan

Perintah Kawalan Pergerakan (PKP) Berdasarkan Parameter Maqāṣid al-Sharī‘ah 
Jurnal Fiqh, Vol. 17 No. 2 (2020) 231-266 